\title{
Article
}

Melissa Clark*

\section{If U.S. Citizens Pose a Risk to International Health, Can the Federal Government Prevent Them from Traveling Abroad?}

https://doi.org/10.1515/jbbbl-2021-2001

Published online August 24, 2021

\begin{abstract}
While states normally controlling public health emergencies, this article discusses the current Centers for Disease Control and Prevention regulations to determine whether the federal agency has the authority to stop ill U.S. citizens from traveling abroad in the event of a public health emergency. The article compares state, federal, and international laws. It also provides an in-depth history of federal quarantine and health recommendations and compares that prior history with the current COVID-19 pandemic.
\end{abstract}

Keywords: CDC, COVID-19, emergency response, federalism, pandemic, public health, travel, tuberculosis, typhoid mary, quarantine

\section{Introduction}

A popular television show discussed a policy idea wherein the fictional version of the State Department would require vaccination records before passports could be issued. ${ }^{1}$ The show inadvertently posed the question: What limits can the federal government impose on citizens attempting to leave the United States $?^{2}$ This paper goes a step further in asking: If citizens are ill, can the federal government stop them from traveling abroad? In order to answer the question, a thorough understanding of local, state, federal, and international law is required.

1 Madam Secretary: The Common Defense (CBS television broadcast Mar. 24, 2019).

2 Id.

*Corresponding author: Melissa Clark, Texas Tech University School of Law, 3311 18th St, Lubbock, TX, USA, E-mail: Melissa.L.Clark@ttu.edu 
The states have the most power over citizens with regard to restricting movement of ill citizens. ${ }^{3}$ The 10th Amendment of the Constitution delegates the "protection of public health and safety" to the police power of the states. ${ }^{4}$ The police powers of the states cover health, safety, and welfare within state borders. ${ }^{5}$ States, through their police powers, can limit public gatherings, impose curfews, and ration goods. ${ }^{6}$ In Gibbons v. Ogden, Chief Justice Marshall indicated those powers included quarantine and isolation. ${ }^{7}$

Since Gibbons, the courts have deferred heavily to the state legislatures, presuming validity of state quarantine laws in the process. ${ }^{8}$ In Jacobson $v$. Massachusetts, the Court indicated the state could enact reasonable regulations to protect state citizens. ${ }^{9}$ There, during a smallpox outbreak in Boston, the state mandated vaccinations to protect the public health and safety. ${ }^{10}$ Jacobson sued for an infringement on his individual rights; however, the Court found that the law was for the common good and it trumped the right of the individual. ${ }^{11}$

Another example of the state's quarantine laws involves the case of Typhoid Mary. ${ }^{12}$ Mary Mallon was a cook in the U.S. after immigrating from Ireland in the late 1800s. ${ }^{13}$ Mary, following her typhoid diagnosis, was sentenced to isolation. ${ }^{14}$ After several lawsuits, she was released on the condition that she never

3 See Gibbons v. Ogden, 22 U.S. 1, 25 (1824).

4 U.S. Const. amend. X; see Jacobson v. Massachusetts, 197 U.S. 11, $24-25$ (1905).

5 See Jorge L. Contreras, Public Health Versus Personal Liberty - The Uneasy Case for Individual Detention, Isolation and Quarantine, 7 The SciTech Lawyer 4 (Spring 2011); Jacobson v. Massachusetts, 197 U.S. at 24-25.

6 See generally Rapid Response was Crucial to Containing 1918 Flu Pandemic, NATIONAL Institutes of HeaLth (Apr. 2, 2007), https://www.nih.gov/news-events/news-releases/rapid-response-wascrucial-containing-1918-flu-pandemic (detailing the actions undertaken by states during the 1918 Influenza pandemic).

7 Gibbons, 22 U.S. at 25; David. P. Fidler, Lawrence O. Gostin, and Howard Markel, Through the Quarantine Looking Glass: Drug Resistant Tuberculosis and Public Health Governance, Law, and Ethics, 35 J. of Law, Medicine, \& Eтнics 616, 620 (2007) (detailing that isolation and quarantine, though used interchangeably, have different meanings. Quarantine is used to explain the process of separating an exposed person from others, whereas isolation is used to explain the process of separating an infected person from others).

8 Fidler, supra note 7 at 621.

9 Jacobson, 197 U.S. at 24-25.

10 Jacobson, 197 U.S. at 27.

11 Jacobson, 197 U.S. at 27-35.

12 See, e.g., Filio Marineli, Gregory Tsoucalas, Marianna Karamanou, and George Androutsos, Mary Mallon (1869-1938) and The History of Typhoid Fever, 26 AnNALS of GASTROENTEROLOGy 132 (2013) (explaining the tuberculosis spread by Mary Mallon and the legal repercussions).

13 Id.

14 Id. at 133. 
again work in food preparation. ${ }^{15}$ Unfortunately, Mary was quite skilled as a cook and she quickly returned to work preparing food for wealthy families. ${ }^{16}$ Following several new typhoid cases, the court sentenced her to isolation, where she remained until her death. ${ }^{17}$ In this case, the state had a very strong interest in protecting the public health and safety-greater than the citizens individual right to freedom. ${ }^{18}$

Since the 1907 Typhoid Mary case, the quarantine laws of the states have been revised. ${ }^{19}$ After the tragic events of September 11, 2001, most states adopted a version of the Model State Emergency Health Powers Act (MSEHPA). ${ }^{20}$ Many MSEHPA versions permit states to order the treatment, isolation, or quarantine of individuals located within a state when the illness is connected to a public health emergency. ${ }^{21}$ While the MSEHPA are only valid to the extent the jurisdictions have enacted them, the MSEPHA were promulgated "by the [Centers for Disease Control and Prevention] and the Center for Law and the Public's Health in the aftermath of the 9/11 attacks."22 The MSEPHA acts enable states to more quickly and more easily quarantine, or impose other restrictions on residents, in the event of a health crisis. $^{23}$

This article focuses primarily on the federal quarantine authority and relevant agencies. ${ }^{24}$ International Law and the World Health Organization are discussed briefly in Part II. ${ }^{25}$ Part III of this article focuses on federal quarantine authority. ${ }^{26}$ Part IV of this article details the development and authority of the most relevant agency to this discussion, the Centers for Disease Control and Prevention (CDC). ${ }^{27}$ In Part V, this article explains the historical applications of federal quarantine. ${ }^{28}$ Part VI answers the title question posed by this article by analyzing which agencies have the legal authority to restrict travel and what tools those agencies could use to prevent citizens from

15 Contreras, supra note 3.

16 Marineli, supra note 12 at 133.

17 Kit Yee Chan \& Daniel D. Reidpath, 'Typhoid Mary' and 'HIV Jane': Responsibility, Agency and Disease Prevention, 11 Reproductive Health Measures 40, 41 (2003).

18 See Marineli, supra note 12.

19 See Contreras, supra note 5.

20 Contreras, supra note 5.

21 Contreras, supra note 5; see The Model State Emergency Powers Act, CENTER fOR LAw \& THE Public's Health, http://www.publichealthlaw.net/MSEHPA/MSEHPA.pdf.

22 Contreras, supra note 5; see The Model State Emergency Powers Act, supra note 21.

23 See Contreras, supra, note 5.

24 See infra Parts III-V.

25 See infra Part II.

26 See infra Part III.

27 See infra Part IV.

28 See infra Part V. 
traveling abroad. ${ }^{29}$ Lastly, Part VII concludes the article and poses an additional query into the effects of asymptomatic carriers during this time of COVID-19. ${ }^{30}$

\section{International Law}

International laws are the least restrictive of the laws in this analysis. ${ }^{31}$ By promulgating guidance, while impacting as little of the nation's sovereignty as possible, international laws are not very rigid. The organization and law most relevant to this article are the World Health Organization (WHO) and the International Health Regulations (IHRs).

The U.N. is composed of six organs-the General Assembly, Security Council, Economic and Social Council, Trusteeship Council, International Court of Justice, and the Secretariat. ${ }^{32}$ Several agencies work within those organs. ${ }^{33}$ The WHO is part of the Economic and Social Council. ${ }^{34}$

The WHO "act[s] as the directing and co-ordinating [sic] authority on international health work." ${ }^{35}$ Within the WHO, several nations make up the World Health Assembly (WHA). ${ }^{36}$ The WHA is the primary administrator for the WHO, and is responsible for policies and budgets. ${ }^{37}$ IHRs "were adopted by the Health Assembly in 1969." "38 The 1969 regulations asked states to report outbreaks of the three illnesses (cholera, plague, and yellow fever). ${ }^{39}$ After SARS, states took efforts to better enhance, support, and strengthen national, regional, and international efforts. ${ }^{40}$ Those efforts led to the WHA resolution in May 2003 to revise the 1969 IHRs. $^{41}$

29 See infra Part VI.

30 See infra Part VII.

31 Compare U.S. Const. amend. X, and The Model State Emergency Powers Act, supra note 21, with World Health Organization, International Health Regulations (2005), https://apps.who.int/iris/ bitstream/handle/10665/246107/9789241580496-eng.pdf;jsessioni$\mathrm{d}=6$ A0D66BB53DC7BB9933652A28A1DFF6C?sequence $=1$.

32 Fact Sheet: THIS IS THE UNITED NATIONS The Six Main Organs, UnitEd NaTions, https://visit. un.org/sites/visit.un.org/files/FS_This_is_the_UN_2013.pdf (last visited Apr. 26, 2020).

33 Id.

34 Id.

35 WHO Const. art 2(a).

36 World Health Organization, supra note 31.

37 World Health Organization, supra note 31.

38 World Health Organization, supra note 31.

39 Frequently asked questions about the International Health Regulations (2005), World Health Organization, https://www.who.int/ihr/about/FAQ2009.pdf (last visited Apr. 26, 2020).

40 See victoria sutton, Biosecurity Law and Policy 460-61 (Vargas Publishing 2014).

41 Revision of the International Health Regulations WHA56.28 (2003); see sutTon, supra note 40 at 460-61. 
The 2005 version of the IHRs "were adopted by the 58th World Health Assembly on 23 May 2005. They entered into force on 15 June 2007."42 The IHR 2005 regulations are concerned with states granting entry to travelers who pose an "imminent public health risk." 43

Under the IHRs, the WHO has declared several public health emergencies of international concern. ${ }^{44}$ The first in 2009 for H1N1 influenza. ${ }^{45}$ In 2014, the WHO declared two public health emergencies of international concern, one for polio and the other for Ebola. ${ }^{46}$ Zika was named a public health emergency of international concern in 2016. ${ }^{47}$ Most recently in 2020, the WHO declared COVID-19 a public health emergency of international concern. ${ }^{48}$

Though the 2005 IHRs do not address whether U.S. citizens can be prevented from leaving a nation, "the international context of foreign travel suggests that the relevant constitutional level of government to prevent persons with dangerous, contagious pathogens from traveling internationally from the United States is the federal government." ${ }^{49}$ As a member of the WHO, and a state nation following the IHRs, the United States has a duty to report and notify WHO for certain specified diseases, "maintain public health measures and response capacity at designated airports," and respond to public health risks and emergencies of international concern. $^{50}$

\section{Federal Quarantine Authority}

Unlike the very expansive quarantine powers of the states, and the very limited international regulations, the federal government falls in the middle. ${ }^{51}$ The U.S.

42 World Health Organization, supra note 31.

43 World Health Organization, supra note 31.

44 Global Health Protection and Security: Intermational Health Regulations (2005), CENTERS FOR DISEASE Control And Prevention (Aug. 19, 2019), https://www.cdc.gov/globalhealth/healthprotection/ghs/ihr/; see Marie Sutton, Forced Quarantine \& Isolation: Does the Law Adequately Balance Individual Rights and Societal Protections?, 39 U. La Verne L. Rev. 98, 126 (2017).

45 Id.

$46 I d$.

47 Id.

48 Rolling updates on coronavirus disease (COVID-19), World Health Organization (Apr. 24, 2020), https://www.who.int/emergencies/diseases/novel-coronavirus-2019/events-as-they-happen; As a result of the recent developments with COVID-19, the disease will play a role in the analysis of this paper.

49 Fidler, supra note 7 at 625.

50 World Health Organization, supra note 31; Sutton, supra note 44 at 108.

51 Compare supra Part I (detailing the state laws on quarantine), with supra Part II (describing the International regulations on quarantine). 
Constitution grants the federal government specific powers with the remainder reserved to the states. ${ }^{52}$ Through the U.S. system of checks and balances, the executive branch-the President-has oversight of the nation's public health policy. ${ }^{53}$ The legislative branch-Congress-sets the administrative parameters, policies, and rules through legislation. ${ }^{54}$ If the act or legislation extends too far, the judicial branch-the Supreme Court-should ensure the agency created by the act and the agency's guiding provisions are constitutional. ${ }^{55}$ "Quarantine ... gives rise to tensions between individual rights and broader community interests." ${ }^{26}$ As such, the federal system of checks and balances safeguards individual rights and liberties, but it also delays the relevant agencies from responding quickly during health threats. ${ }^{57}$

Federal quarantine oversight begins with interstate commerce. ${ }^{58}$ Biological agents do not recognize state borders and they can bring a nation to their heelscrippling the economy, causing panic, and severely impacting public health. Though the states are thought to have quarantine powers as part of their police powers, the federal government has firmly established the power to oversee interstate travel and commerce. ${ }^{59}$ As a result of the authority over interstate commerce, the federal government has oversight over the interstate transmission of disease as well. ${ }^{60}$ With that power, Congress passed the first Quarantine Act. ${ }^{61}$ Congress has amended the Quarantine Act several times, each time broadening the federal government's control, but never preempting the states' role in isolation and quarantine. $^{62}$

52 U.S. Const. art. I, § 8.

53 Lawrence O. Gostin, When Terrorism Threatens Health: How Far are Limitations on Personal and Economic Liberties Justified?, 55 FLA. L. Rev. 1105, 1163 (Dec. 2003).

54 Id.

55 Id.

56 Michelle A. Daubert, Pandemic Fears and Contemporary Quarantine: Protecting Liberty Through a Continuum of Due Process Rights, 54 Buff. L. Rev. 1299, 1310 (Jan. 2007).

57 Gostin, supra note 53 at 1164.

58 See Felice Batlan, Law in the Time of Cholera: Disease, State Power and Quarantines Past and Future, 80 Temp. L. Rev. 53, 64 (2007); Contreras, supra note 5.

59 See id.

60 See generally Quarantine and Isolation: Legal Authorities for Isolation and Quarantine, Centers for Disease Control and Prevention (Feb. 24, 2020), https://www.cdc.gov/quarantine/ aboutlawsregulationsquarantineisolation.html (outlining the CDC's legal authority to quarantine). 61 James J. Misrahi, The CDC's Communicable Disease Regulations: Striking the Balance Between Public Health and Individual Rights, 67 EмоRу L.J. 463, 464 (2018); See Batlan, supra note 51 at 64; Contreras, supra note 5.

62 Misrahi, supra note 61 at 464. 
The Quarantine Act was replaced in 1944 when Congress passed the Public Health Service Act (PHSA). ${ }^{63}$ The Act is codified in 42 U.S.C. ch. 6A $\S 201$ et seq. ${ }^{64}$ The Act was intended to clear up confusion from the 1893 Quarantine Act. ${ }^{65}$ The Act "explicitly conferred the authority ... to isolate infected persons for the purpose of interstate rather than foreign quarantine." 66 Congress intended for the statute to be so broad as to include any disease designated quarantinable by the President of the United States. ${ }^{67}$

The Department of Health and Human Services (HHS) was created by the PHSA. $^{68}$ The Secretary is authorized "to promulgate and enforce regulations ... necessary to prevent the introduction, transmission, or spread of communicable disease." ${ }^{99}$ Within the PHSA, the legal authority for the spread of the communicable diseases is found within 42 U.S.C. Section 264(a). ${ }^{70}$ Paragraphs (c) and (d) are related to travelers, with (c) covering foreign arrivals to the U.S. and (d) covering domestic interstate travelers. ${ }^{71}$

The HHS and its subagencies and divisions are primarily tasked with quarantine and isolation of individuals traveling amongst or entering into the United States. ${ }^{72}$ There are several other agencies tasked with federal isolation and quarantine; however, most of them are tasked with oversight of the importation and exportation of goods or animals. ${ }^{73}$ For example, the U.S. Department of Fish and Wildlife has federal quarantine authority over certain animals entering the country-bats are one example. ${ }^{74}$ During an influenza pandemic, the U.S. Department of Agriculture monitors livestock, poultry, and swine for spread of the disease and the U.S. Fish and Wildlife Service reports

63 Misrahi, supra note 61 at 464.

6442 U.S.C. ch. 6 A § 201 et seq.

65 Misrahi, supra note 61 at 465.

66 Misrahi, supra note 61 at 465 (internal quotations removed).

67 Misrahi, supra note 61 at 465.

68 Contreras, supra note 5.

69 Contreras, supra note 5.; see generally 42 U.S.C. $\$ 270$ (noting the Officer of Surgeon General was replaced by the Secretary of Health, Education, and Welfare, which was replaced by the Secretary of Health and Human Services).

7042 U.S.C. $\S 264(a)$.

71 Id. $\S \S 264(\mathrm{c})-(\mathrm{d})$.

72 See generally Quarantine and Isolation: Legal Authorities for Isolation and Quarantine, CENters for Disease Control and Prevention (Feb. 24, 2020), https://www.cdc.gov/quarantine/ aboutlawsregulationsquarantineisolation.html (outlining the CDC's legal authority to quarantine). 73 See generally Barbara Jester, Timothy Uyeki, and Daniel Jernigan, Readiness for Responding to a Severe Pandemic 100 Years After 1918, 187 Aм J EpidEmiol. 2596, 2597 (2018) (outlining agency coordination).

74 Importation: Bringing Bats into the United States, Centers for Disease Control and Prevention (Sept. 1, 2016), https://www.cdc.gov/importation/bringing-an-animal-into-the-united-states/ bats.html. 
avian deaths to the $\mathrm{CDC} .^{75}$ However, with regard to ill individuals, the CDC is the lead agency. $^{76}$

\section{Centers for Disease Control and Prevention}

The CDC operates within the HHS. ${ }^{77}$ The HHS delegates the responsibility for federal quarantine of individuals at ports of entry to the CDC. ${ }^{78}$ The quarantine stations, located at nearly two dozen ports of entry, are run by the Division of Global Migration and Quarantine, a CDC division. ${ }^{79}$

The "CDC is authorized to detain, medically examine, and release persons arriving into the United States and traveling between states who are suspected of carrying these communicable diseases." ${ }^{80}$ According to paragraph (b) of the PHSA, the President must issue an executive order to add or remove diseases from the quarantinable list. ${ }^{81}$ Federal quarantine and isolation are currently authorized for several illnesses: cholera, diphtheria, tuberculosis, plague, smallpox, yellow fever, viral hemorrhagic fever, SARS, and influenza. ${ }^{82}$ Viral hemorrhagic fevers, which include Ebola and SARS, are the two most recent additions to the list. ${ }^{83}$

Historically, the CDC has not ordered quarantine or isolation of many individuals. ${ }^{84}$ On average, the $\mathrm{CDC}$ issues one isolation order a year for travelers known to be infected with tuberculosis. ${ }^{85}$ In those cases, the CDC arranges, when needed, transport of the infected individuals to out of state hospitals and then passes their care to the local public health department. ${ }^{86}$

75 Jester, supra note 73.

76 See 42 U.S.C. § 264; see generally Quarantine and Isolation: Legal Authorities for Isolation and Quarantine, Centers for DiseAse Control and PREvention (Feb. 24, 2020), https://www.cdc.gov/ quarantine/aboutlawsregulationsquarantineisolation.html (outlining the CDC's legal authority to quarantine).

77 See generally Quarantine and Isolation: Legal Authorities for Isolation and Quarantine, supra note 76 (outlining the CDC's legal authority to quarantine).

78 Misrahi, supra note 61 at 466.

79 Misrahi, supra note 61 at 466.

80 Quarantine and Isolation: Legal Authorities for Isolation and Quarantine, supra note 76.

8142 U.S.C. § 264(b); see Fidler, supra note 7 at 62; Misrahi, supra note 61 at 467.

82 Quarantine and Isolation: Legal Authorities for Isolation and Quarantine, supra note 76.

83 Sutton, supra note 44 at 108.

84 See Misrahi, supra note 61 at 470.

85 Misrahi, supra note 61 at 470; see infra Part IV.A for an example of a CDC quarantine of a tuberculosis patient.

86 Centers for Disease Control and Prevention, Public Health Interventions Involving Travelers with Tuberculosis-U.S. Ports of Entry, 2007-2012, 61 Morbidity and MoRtality WKLy. ReP. No. 30, 570 (Aug. 3, 2012). 


\subsection{Do Not Board List}

The CDC proposed regulations in 2005 to expand reporting requirements for flights arriving from foreign nations. ${ }^{87}$ Through those efforts, the Do Not Board List (DNB) was created. ${ }^{88}$ The DNB went into effect in $2007 .^{89}$ The DNB is managed jointly by the CDC and the Department of Homeland Security (DHS). ${ }^{90}$ The list is managed primarily by the Transportation Security Administration (TSA)-a part of Homeland Security since 2003. ${ }^{91}$

The list is designed to stop citizens with communicable diseases from traveling before they board aircraft either leaving from or heading toward a U.S. airport, or to prevent travelers with a communicable disease from crossing the borders. ${ }^{92}$ The $\mathrm{CDC}$ has strict rules controlling the process of adding ill persons to the list. ${ }^{93}$

To include someone on the list, CDC must determine that the person (1) likely is contagious with a communicable disease that would constitute a serious public health threat should the person be permitted to board a flight; (2) is unaware of or likely to be nonadherent with public health recommendations, including treatment; and (3) likely will attempt to board a commercial aircraft. ${ }^{94}$

The list has been effective at monitoring foreign arrivals known to have tuberculosis (TB). ${ }^{95} \mathrm{~A}$ bacterial infection, tuberculosis attacks the lungs and is spread by coughing and sneezing. ${ }^{96}$ It is usually treated by antibiotics, however, one strain of TB is drug resistant and another is limited to treatment from only a few antibiotics. ${ }^{97}$ The "CDC

87 See Centers for Disease Control and Prevention, Federal Air Travel Restrictions for Public Health Purposes - United States, June 2007-May 2008, 57 Morbidity and Mortality WkLy. Rep. No. 37, 1009 (Sept. 19, 2008).

88 Id.

89 Id.

90 Id.

91 Misrahi, supra note 61 at 470; TSA at a Glance, Transportation Security Administration, https:// www.tsa.gov/press/factsheets/tsa-glance (last visited Apr. 26, 2020).

92 TSA at a Glance, supra note 91.

93 See Centers for Disease Control and Prevention, Federal Air Travel Restrictions for Public Health Purposes - United States, June 2007-May 2008, supra note 87.

94 Centers for Disease Control and Prevention, Federal Air Travel Restrictions for Public Health Purposes - United States, June 2007-May 2008, supra note 87.

95 See Centers for Disease Control and Prevention, Federal Air Travel Restrictions for Public Health Purposes - United States, June 2007-May 2008, supra note 87 at 1010.

96 Kathleen S. Swendiman and Nancy Lee Jones, Cong. Research Serv., Rl34144, Extensively DrugResistant Tuberculosis (XDR-TB): Emerging Public Health Threats and Quarantine and Isolation 1 (2010). 97 Id. 
receives approximately 125 reports each year of arriving travelers with active TB." 98 To date, most of the individuals placed on the DNB had tuberculosis. ${ }^{99}$

Additionally, a border lookout record, notifying customs agents of serious public health threats, is often created by the CDC and DHS when a person is placed on the DNB. ${ }^{100}$ The border lookout record detects attempts to cross borders of the U.S., through land or sea, and requires the U.S. Customs and Border Patrol notify the CDC. ${ }^{101}$

\subsection{Regulation Changes}

The DNB shows the CDC's authority as of 2007 to isolate, quarantine, or arrange transportation of individuals known to have a quarantinable disease. However, the CDC authority expanded further in 2017, to achieve faster response times in the event of public health emergencies. ${ }^{102}$ The provisions that went into effect in 2017 are

designed to better facilitate the identification of ill persons onboard conveyances and at ports of entry, to allow the CDC to issue travel permits for the controlled movement of potentially infected persons across state lines, and various other provisions designed to accord individuals under federal isolate, quarantine, or conditional release with necessary due process. ${ }^{103}$

As part of the changes, the definitions sections of the applicable authority were expanded. ${ }^{104}$ The first relevant definition for this analysis is for ill person. It is defined as an individual who has either a persistent fever, or who has a fever and another symptom, or someone with "indications of communicable disease."105 Communicable diseases are illnesses from infectious agents, transmitted from either another person or an animal. ${ }^{106}$

The illness stages are defined as qualifying stage or precommunicable stage. ${ }^{107}$ A qualifying stage means either the "communicable stage of a quarantinable

98 Centers for Disease Control and Prevention, Public Health Interventions Involving Travelers with Tuberculosis-U.S. Ports of Entry, 2007-2012, supra note 86.

99 Centers for Disease Control and Prevention, Federal Air Travel Restrictions for Public Health Purposes - United States, June 2007-May 2008, supra note 87 at 1010.

100 Centers for Disease Control and Prevention, Federal Air Travel Restrictions for Public Health Purposes - United States, June 2007-May 2008, supra note 87 at 1011.

101 Sutton, supra note 44 at 108.

102 Misrahi, supra note 61 at 472.

103 Misrahi, supra note 61 at 472.

104 Misrahi, supra note 61 at 472-73.

10542 C.F.R. § 70.1 (2017).

106 Id.

107 See id. 
communicable disease or the precommunicable stage of the quarantinable communicable disease, but only if the quarantinable communicable disease would be likely to cause a public health emergency ... "108 A precommunicable stage means the "individual's earliest opportunity for exposure to an infectious agent and ending upon entering or reentering the communicable state" or "the latest date at which the individual could reasonably be expected to have the potential to enter ... the communicable stage."109

Further, in order to understand the illness stages, the new definitions include public health emergency and reasonably believed. ${ }^{110}$ A public health emergency means:

(1) Any communicable disease event as determined by the Director with either documented or significant potential for regional, national, or international communicable disease spread or that is highly likely to cause death or serious illness if not properly controlled; or

(2) Any communicable disease event described in a declaration by the Secretary ...; or

(3) Any communicable disease event the occurrence of which is notified to the World Health Organization, in accordance with Articles 6 and 7 of the International Health Regulations, as one that may constitute a Public Health Emergency of International Concern; or

(4) Any communicable disease event the occurrence of which is determined by the Director-General of the World Health Organization, in accordance with Article 12 of the International Health Regulations, to constitute a Public Health Emergency of International Concern; or

(5) Any communicable disease event for which the Director-General of the World Health Organization, in accordance with Articles 15 or 16 of the International Health Regulations, has issued temporary or standing recommendations for purposes of preventing or promptly detecting the occurrence or reoccurrence of the communicable disease. ${ }^{111}$

Additionally, a reasonable belief of infection is defined as the

specific articulable facts upon which a public health officer could reasonably draw the inference that an individual has been exposed ... to the infectious agent that causes a quarantinable communicable disease ... and that as a consequence of the exposure, the individual is or may be harboring in the body the infectious agent of that quarantinable communicable disease. ${ }^{112}$

108 Id. (emphasis added).

109 Id.

110 Misrahi, supra note 61 at 473.

11142 C.F.R. $\S 70.1$ (2017) (emphasis added).

112 Id. 
The definitions are important to understand the regulations contained in the PHSA and the breadth of application available to the CDC, and they provide insight into the full scope of the authority granted the agency. According to part 42 C.F.R. part 70.6, the Director (by delegation the CDC):

may authorize the apprehension, medical examination, quarantine, isolation, or conditional release for the purpose of preventing the introduction, transmission, and spread of quarantinable communicable diseases $\ldots$ based upon a finding that:

(1) The individual is reasonably believed to be infected with a quarantinable communicable disease in a qualifying stage and is moving or about to move from a State into another State; or

(2) The individual is reasonably believed to be infected with a quarantinable communicable disease in a qualifying stage and constitutes a probable source of infection to other individuals who may be moving from a State into another State. ${ }^{113}$

Based on the authority granted, the CDC and the expanded definitions, the CDC can authorize apprehension or medical exams of individuals if there is a reasonable belief the individual is infected with quarantinable disease in the qualifying state and that individual is moving or about to move from a state into another state. ${ }^{114}$ The CDC can also apprehend an individual if that individual is a probable source of infection to other individuals moving from a state to another state through the language in the precommunicable stage definition, if that individual may have a quarantinable communicable disease likely to cause a public health emergency. ${ }^{115}$

\section{Historical Uses of Federal Quarantine Power}

\subsection{Federal Quarantine}

The federal government's first issued quarantine order was in the 1960 s. ${ }^{116}$ Ellen Siegel was quarantined by the precursor agency to the CDC in 1963 after arriving in the U.S. from Sweden-a country undergoing a smallpox outbreak. ${ }^{117}$ Unable to

11342 C.F.R. $\S 70.6$ (2017).

114 See 42 C.F.R. $\S 70.1$ and 70.6 (2017).

115 Misrahi, supra note 61 at 473 (quoting Control of Communicable Diseases, 82 Fed. Reg. 6890 (Jan. 19, 2017)).

116 Misrahi, supra note 61 at 468.

117 Misrahi, supra note 61 at 469. 
show inoculation for the disease, and with a history of unsuccessful vaccinations, the federal government held Siegel in quarantine for 14 days. ${ }^{118}$

For only the second time in history, the CDC issued isolation orders for a patient-this time the infection was tuberculosis-in 2007. ${ }^{119}$ In this case, the individual was diagnosed with tuberculosis in Atlanta, Georgia by the local health department. ${ }^{120}$ After reporting the diagnosis to the CDC, the CDC began testing the individual for various strains of the disease. ${ }^{121}$ In between tests for different strains, the CDC informed the individual not to board an international flight. ${ }^{122}$ Defying health care professionals, he flew abroad for his wedding and honeymoon anyway. ${ }^{123}$ While in Italy, the CDC contacted him and urged him to check in to an Italian hospital. ${ }^{124}$ The individual, again, ignored the advice. ${ }^{125}$ Instead, he flew to Canada, rented a car, and returned to the United States. ${ }^{126}$ He was flagged at the U.S.-Canadian border but he was not stopped by U.S. border patrol. ${ }^{127}$ Upon his return, he was issued quarantine orders by the CDC. ${ }^{128}$

The individual later sued the HHS and the CDC because the CDC released his information to warn other travelers from his flights of the dangers he presented to their health and urged the passengers to be tested for tuberculosis. ${ }^{129}$ Even though the 2005 IHRs had not yet gone into effect, the U.S. complied with the notice requirements and informed the WHO of a public health emergency of international concern. ${ }^{130}$ As a result of the individual's travel, two congressional hearings were held and two reports were issued. ${ }^{131}$ Additionally, the DNB list and border lookout record procedures were created to track known tuberculosis patients attempting to enter or leave the U.S. ${ }^{132}$

118 Misrahi, supra note 61 at 469.

119 See Speaker v. US Dep't of Health \& Human Servs. Centers for Disease Control \& Prevention, 680 F. Supp.2d 1359, 1361 (N.D. Ga. 2009).

120 Swendiman, supra note 96.

121 Speaker, 680 F. Supp.2d at 1360-1361.

122 Swendiman, supra note 96.

123 Swendiman, supra note 96.

124 Speaker, 680 F. Supp.2d at 1360-1361.

125 Swendiman, supra note 96 at 2.

126 Speaker, 680 F. Supp.2d at 1360-1361.

127 Swendiman, supra note 96.

128 Speaker, 680 F. Supp.2d at 1361; Swendiman, supra note 96.

129 Speaker, 680 F. Supp.2d at 1361.

130 Fidler, supra note 7 at 625.

131 See, e.g., Swendiman, supra note 96.

132 Centers for Disease Control and Prevention, Public Health Interventions Involving Travelers with Tuberculosis-U.S. Ports of Entry, 2007-2012, supra note 86. 
Because the CDC rarely issues quarantine orders, especially outside of TB, it was surprising when President Trump recently threatened regional quarantines around New York following the current outbreak of COVID-19. ${ }^{133}$ COVID-19 is a coronavirus that also attacks the lungs. ${ }^{134}$ Early research indicates that it is transmitted by coughing or through contact with a person either showing symptoms or within one or two days before showing symptoms. ${ }^{135}$ Recently, it became known that healthy individuals can be asymptomatic carriers-unknowingly spreading the COVID-19 virus in the community. ${ }^{136}$ Shortly after the President's interest in regional quarantine was announced, it was abandoned. ${ }^{137}$

\subsection{Federal Recommendations}

On top of the federal quarantine ability, the federal government has the ability to make recommendations to the states. ${ }^{138}$ In 1918, the federal government issued recommendations to prevent the influenza spread. ${ }^{139}$ At the time, the Spanish Influenza, or H1N1 influenza, infected approximately half of the world's population. ${ }^{140}$ As a result of the disease, around 500 million people died worldwide. ${ }^{141}$ Then Surgeon General Blue issued orders to the local health departments to close or suspend public activities. ${ }^{142}$ The states responded by closing schools, churches, and other places of public assembly. ${ }^{143}$ Some of the states instituted rules for

133 Trump Backtracks After Cuomo Criticizes Quarantine Idea, New York Times (Mar. 28, 2020), https://www.nytimes.com/2020/03/28/nyregion/coronavirus-new-york-update.html.

134 What you should know about COVID-19 to protect yourself and others, CENTERS FOR DISEASE Control and Prevention, https://www.cdc.gov/coronavirus/2019-ncov/downloads/2019-ncov-factsheet.pdf (last visited Apr. 25, 2020).

135 Id.

136 Eric Lipton, David E. Sanger, Maggie Haberman, Michael D. Shear, Mark Mazzetti, and Julian E. Barnes, He Could Have Seen What Was Coming: Behind Trump's Failure on the Virus, THE New York Times (Apr. 11, 2020).

137 Trump Backtracks After Cuomo Criticizes Quarantine Idea, supra note 133.

138 See, e.g., Misrahi, supra note 61 at 468 (explaining how the surgeon general of the U.S. issued recommendations in 1918).

139 Id.

140 Jester, supra note 73.

141 Influenza (Flu): 1918 Pandemic (H1N1 virus), Centers for Disease Control and Prevention (Mar. 20, 2019), https://www.cdc.gov/flu/pandemic-resources/1918-pandemic-h1n1.html.

142 Misrahi, supra note 61 at 468.

143 Rapid Response was Crucial to Containing 1918 Flu Pandemic, National Institutes of Health (Apr. 2, 2007), https://www.nih.gov/news-events/news-releases/rapid-response-was-crucialcontaining-1918-flu-pandemic; see Misrahi, supra note 61 at 468. 
wearing face masks in public. ${ }^{144}$ According to studies conducted by the National Institute of Health, the rapid response and social distancing measures significantly reduced the number of deaths associated with the influenza pandemic. ${ }^{145}$

Similarly, in 2020, President Trump, at the advice of the Secretary of the HHS and National Security Council, issued nonbinding orders directing the states to issue stay at home orders. ${ }^{146}$ The President's recommendation of social distancing was taken up by the states. ${ }^{147}$ However, the President elected to limit the Secretary of HHS's authority as a result, and Vice President Pence took oversight of advice and media statements. ${ }^{148} \mathrm{~A}$ few weeks later, the President released guidelines to assist the state governors with reopening their states. ${ }^{149}$

\subsection{Halting Air Travel and Closing Borders}

Additionally, the President has the authority to halt travel with other nations. ${ }^{150}$ President Kennedy took it to an extreme in 1963 when he halted travel to Cuba. ${ }^{151}$ Whether President Kennedy had the sole authority to halt travel to Cuba during the Cuba Missile Crisis is unclear; however, the President can approve regulations to close borders to prevent the spread of disease. ${ }^{152}$ For many of the border control authorities to become effective, the country needs to be under an emergency declaration. ${ }^{153}$ Once declared, Congress has granted the President broad authority to place restrictions on non-essential travel. ${ }^{154}$

144 Rapid Response was Crucial to Containing 1918 Flu Pandemic, supra note 143.

145 Rapid Response was Crucial to Containing 1918 Flu Pandemic, supra note 143.

146 Peter Baker, Zolan Kanno-Younga, and Alan Rappenport, Torn Over Reopening Economy, Trump Says He Faces 'Biggest Decision I've Ever Had to Make’, The New York Times (Apr. 10, 2020); Lipton, supra note 136.

147 See Baker, supra note 146.

148 Lipton, supra note 136.

149 Alana Wise, READ: White House Guidelines to States for Reopening, NPR (Apr. 16, 2020), https://www.npr.org/2020/04/16/836489480/read-white-house-guidelines-to-states-for-

reopening.

150 See, e.g., Immigration and Nationality Act, $\S 212$ (f) (finding the entry "detrimental to the interests of the United States").

151 Karen DeYoung, Julie Vitkovskaya, Kennedy Elliott, Julie Tate and Swati Sharma, A difficult history between U.S. and Cuba, THE WaShington Post (Dec. 17, 2014), https://www.washingtonpost. com/wp-stat/graphics/world/cuba-2014/timeline/index.html (last visited Apr. 25, 2020).

15242 U.S.C. $\S 265$.

153 Kelsey Y. Santamaria and Ben Harrington, Cong. Research Serv., LSB10439, Entry Restrictions at the Northern ANd Southern Borders in Response to COVID-19 (2020).

154 Id. 
One of the ways in which the President can control the borders is through the U.S. Customs and Border Patrol. ${ }^{155}$ Through the Tariff Act of 1930, the U.S. Customs and Border Patrol has the ability to limit services at ports of entry. ${ }^{156} \mathrm{~A}$ broad authority granted when there are "specific threats to human life or national interests," the Act allows for limits on the number of individuals entering the country. ${ }^{157}$

Additionally, DHS has the authority to temporarily close U.S. borders to protect national interests. ${ }^{158}$ Following the Ebola outbreak in 2014, and the Dallas patient's death from it, President Obama issued travel restrictions for passengers arriving from Liberia, Sierra Leone, and Guinea. ${ }^{159}$ Anyone arriving from those three countries was to be routed to one of five designated airports and the individuals were to have their temperature taken before being admitted into the U.S. ${ }^{160}$

In 2020, President Trump imposed air travel restrictions for non-U.S. citizens who traveled to China within the preceding two weeks. ${ }^{161}$ The WHO declaration of a global health emergency, and the recent person-to-person spread in the U.S., changed the administration's view that travel restrictions are counterproductive for controlling biological concerns. ${ }^{162}$ Despite the controls on travelers entering the U.S., in the House subcommittee hearing on February 5, 2020, Mr. Ron Klain, former White House Ebola Coordinator, stated “[t]here's no restriction on Americans going back and forth." 163

Even though the WHO issued the global health emergency declaration, the WHO issued a statement just after President Trump's announcement, “...reiterat [ing] our call to all countries not to impose restrictions inconsistent with the

155 Id.

156 Id.

15719 U.S.C. § 1318; see Santamaria, supra note 153.

158 Ben Harrington, Cong. Research Serv., LSB10283, Can the President Close the Border? Relevant LAWS AND CONSIDERATIONS (2019).

159 FACT SHEET: The U.S. Government's Response to Ebola at Home and Abroad, THE WhiTE HousE (Oct. 22, 2014), https://obamawhitehouse.archives.gov/the-press-office/2014/10/22/fact-sheet-usgovernment-s-response-ebola-home-and-abroad.

$160 \mathrm{Id}$.

161 Proclamation No. 9994, 85 F.R. 15337 (Mar. 13, 2020).

162 Lipton, supra note 136.

163 The Wuhan Coronavirus: Assessing the Outbreak, the Response, and Regional Implications Before the Subcomm. On Asia, the Pacific, and Nonproliferation, 116th Congress (2020) (statement by Ron Klain) (available online at https://foreignaffairs.house.gov/hearings?ID=41B2E5E9-E5F84869-94F0-019DB3DFD037). 
International Health Regulations. Such restrictions can have the effect of increasing fear and stigma, with little public health benefit." ${ }^{164}$ Within a month, the Trump administration announced additional travel restrictions from Europe. ${ }^{165}$ The Department of State issued Level 3 Health Advisories for international travel and Level 4 Advisories (or Do Not Travel) for China. ${ }^{166}$

Also, as a result of COVID-19, President Trump suspended non-essential travel between Canada and Mexico. ${ }^{167}$ Touted as a mutual decision, the restrictions on the borders are temporary and are expected to end May 20, 2020. ${ }^{168}$ The order came from the Director of the CDC, pursuant to the Public Health Service Act. ${ }^{169}$ Sections 265 and 268 allow the Director to suspend entries at the border if a dangerous communicable disease is present in a neighboring foreign nation. ${ }^{170}$ In this case, the order suspends foreign travelers but does not apply to U.S. citizens. ${ }^{171}$ As such, the guidance would not stop a U.S. citizen from leaving the U.S. or from reentering. ${ }^{172}$

164 WHO Director-General's opening remarks at the technical briefing on 2019 novel coronavirus, World Health Organization (Feb. 4, 2020), https://www.who.int/dg/speeches/detail/who-directorgeneral-s-opening-remarks-at-the-technical-briefing-on-2019-novel-coronavirus.

165 Ethan Epstein, Donald Trump Never Actually Banned Flights From China or Europe. Why?, WASHington Times (Mar. 22, 2020), https://www.washingtontimes.com/news/2020/mar/22/trumpnever-actually-banned-flights-from-china-or-/ (last visited Apr. 1, 2020).

166 Control of Communicable Diseases; Foreign Quarantine: Suspension of Introduction of Persons into United States from Designated Foreign Countries or Places for Public Health Purposes, 85 Fed. Reg. 16,559 (Mar. 24, 2020).

167 Jeremy Diamond, US and Canada Suspend Non-essential Travel Between the Two Countries, CNN (Mar. 18, 2020), https://www.cnn.com/2020/03/17/politics/us-canada-suspend-travel/ index.html (last visited Apr. 25, 2020); Vivian Salama, White House using legal lessons learned in travel ban fights in coronavirus travel restrictions, CNN (Mar. 24, 2020), https://www.cnn.com/ 2020/03/24/politics/white-house-counsels-office-coronavirus/index.html (last visited Apr. 25, 2020).

168 Santamaria, supra note 153.

169 Extension of Order Under Sections 362 and 365 of the Public Health Service Act; Order Suspending Introduction of Certain Persons from Countries Where a Communicable Disease Exists, 85 Fed. Reg. 22,424 (Apr. 20, 2020).

17042 U.S.C. $\S \S 265,268$.

171 Extension of Order Under Sections 362 and 365 of the Public Health Service Act; Order Suspending Introduction of Certain Persons from Countries Where a Communicable Disease Exists, 85 Fed. Reg. 22,424 (Apr. 20, 2020).

172 See generally Extension of Order Under Sections 362 and 365 of the Public Health Service Act; Order Suspending Introduction of Certain Persons from Countries Where a Communicable Disease Exists, 85 Fed. Reg. 22,424 (Apr. 20, 2020) (“This order does not apply to U.S. citizens, lawful permanent residents, and their spouses and children"). 


\section{In a Word, Yes}

However, it is important that President Trump has not halted travel from the U.S. nor has the President, by executive order, named COVID-19 as one of the communicable diseases for which federal quarantine powers are authorized. By not designating it a quarantinable disease, the CDC is more limited in authority. ${ }^{173}$ With that said, the answer to the title question posed by this article-if U.S. citizens pose a risk to international health, can the federal government prevent them from traveling abroad?-is most likely yes, but it depends.

Prior to 2007, the CDC would not be able to stop an infected person from traveling internationally, only the state and local health departments would have had the authority. ${ }^{174} \mathrm{~A}$ tuberculosis patient, in fact, did just that. ${ }^{175} \mathrm{As}$ a result, the PHSA was amended to allow for greater control over flights by two agencies: CDC and TSA. ${ }^{176}$ Following the public health emergency of international concern for Ebola, the regulations were amended yet again to grant the CDC additional authority during a public health emergency. ${ }^{177}$ As a result of those changes, the CDC is now in a position to stop a traveler under several different scenarios.

Prior to 2017, to federally quarantine or isolate an individual-unless the individual was ill with one of the diseases on the quarantine list-the President would first have to issue an executive order adding the disease to the list before the CDC would have the authority to act. ${ }^{178}$ Without the disease on the list, the CDC would be relegated to advising the local or state public health department in the state where the ill person was located. ${ }^{179}$

173 Misrahi, supra note 61 at 485.

174 See generally Speaker v. US Dep't of Health \& Human Servs. Ctrs. for Disease Control \& Prevention, 680 F. Supp.2d 1359 (N.D. Ga. 2009) (noting the CDC did not stop the citizen from traveling abroad).

175 See id.

176 See Centers for Disease Control and Prevention, Federal Air Travel Restrictions for Public Health Purposes - United States, June 2007-May 2008, supra note 87 at 1009; Misrahi, supra note 61 at 473 and 486.

177 See generally Public Health Emergency Preparedness and Response Capabilities, CENTERS FOR Disease Control and Prevention (Nov. 19, 2018), https:/www.cdc.gov/cpr/readiness/capabilitieschange.htm ("In 2017, CDC began updating the capabilities in response to lessons learned from public health emergency responses, updates to public health preparedness science, revised guidance and resources, findings from internal reviews and assessments").

178 See generally Denver Nicks, The CDC Has Less Power Than You Think, and Likes it That Way, TIME (Oct. 17, 2014 1:12 PM), https://time.com/3516827/cdc-constitution-quarantine/ (noting the CDC's "power to act is extremely restricted").

179 Id. 
In contrast, under the new regulations, if a U.S. citizen falls within the ill person definition, and is likely to cause a public health emergency as defined by the new regulations, the $\mathrm{CDC}$ would be allowed to detain the individual even if that communicable disease was not on the executive order quarantine list. ${ }^{180}$ The CDC would only be able to quarantine or isolate ill persons for $72 \mathrm{~h}$ without taking additional steps-including an assessment of the least restrictive means and medical exam. ${ }^{181}$ The CDC only needs a reasonable belief the individual was exposed to, and possibly harboring, a communicable disease. ${ }^{182}$

With that said, while the PHSA is concerned primarily with foreign arrivals and interstate travel, it does not specifically address ill persons leaving the country. ${ }^{183}$ However, if the U.S. citizen were attempting to board an aircraft with no layovers in another state, the CDC could probably stop the citizen from leaving the country, so long as that citizen posed a public health emergency.

This expansive regulation would only be possible through a broad expansion of the interstate commerce clause. In United States v. Lopez and in Wickard $v$. Filburn, the Court found that the federal government has the authority to regulate wholly intrastate activities. ${ }^{184}$ In Lopez, the Court said the Commerce Clause broadly includes and regulates "the instrumentalities of interstate commerce, or persons or things in interstate commerce, even though the threat [to interstate commerce] may come only from intrastate activities."185

The 2017 regulations in 42 C.F.R. part 70.5, dealing with CDC travel permits, applies to "individuals traveling entirely intrastate and to conveyances that transport such individuals upon the rest of a State ..." or in the event of "inadequate local control."186 What would constitute an inadequate local control measure is unclear; however, in part 70.2 it states that if measures taken by health authorities are insufficient to prevent the spread of any of the quarantinable diseases, the Secretary may take measures to prevent spread as deemed reasonably necessary. ${ }^{187}$

According to the new regulations, the CDC can even implement prevention measures at locations where individuals "gather to engage in interstate travel, even if such locations are traditionally only associated with intrastate travel."188

180 See Misrahi, supra note 61 at 473 and 486.

181 See Misrahi, supra note 61.

182 Misrahi, supra note 61 at 484.

183 Swendiman, supra note 96.

184 Wickard v. Filburn, 317 U.S. 111 (1942); U.S. v. Lopez, 514 U.S. 549 (1995).

185 Lopez, 514 U.S. at 558-59; see Misrahi, supra note 61 at 481.

186 Misrahi, supra note 61 at 481 (internal quotations omitted).

18742 C.F.R. $\S 70.2$ (2017).

188 Misrahi, supra note 61 at 481. 
Coupling that authority with 42 C.F.R. part 70.6, where apprehension is authorized if the individual is reasonably believed to be infected in a qualifying state or is a probable source of infection to others by moving from a state to state, the CDC could prevent travel from an individual who is infected and goes to an airport or port. $^{189}$

Adding to that, the broad definition of public health emergency, where the CDC has the ability to isolate or quarantine individuals to prevent the spread of "communicable disease events or occurrences with documented or significant potential for regional, national, or international spread," the CDC would have the authority to stop a U.S. citizen from traveling abroad if the citizen was suffering from a quarantinable illness, or perhaps, even if the individual was only within the precommunicable stage of the illness. ${ }^{190}$

With that said, implementing all of the required steps-timely enough to stop a person from boarding an aircraft-is still problematic for the CDC. Before the CDC would know of an individual's illness (or potential illness) the state and local public health officials would need to be aware of the individual's health and report it to the CDC. At that point, the local and state officials would be in the best place to issue quarantine or isolation orders if they were worried about spread. However, as mentioned above, if the local health authorities did not stop the citizen from traveling, and the CDC was notified of the individual's condition, the CDC could step in based on inadequate local control measures.

Other agencies-namely the U.S. Customs and Border Protection and the Transportation Security Administration-also have the ability to stop ill persons from traveling across the border. However, the CDC is the primary agency tasked with controlling the spread of infectious diseases. ${ }^{191}$

\section{Conclusion}

The United States has a duty under the 2005 IHR regulations to monitor incoming travelers and to report outbreaks of diseases within the United States. ${ }^{192}$ However, the IHR does not mandate limits the U.S. may impose upon its own citizens attempting to leave the country. ${ }^{193}$

18942 C.F.R. $\S 70.2,70.6$.

19042 U.S.C. § 264(a); 42 C.F.R. § 70.2, 70.6.

191 See 42 U.S.C. § 264; see generally Quarantine and Isolation: Legal Authorities for Isolation and Quarantine, supra note 76.

192 World Health Organization, supra note 38.

193 See World Health Organization, supra note 38. 
Unlike most of the regulations for stopping travel at the borders that deal with prohibiting foreign entries, the CDC is authorized to quarantine or isolate individuals in the interest of public health if they pose a risk to state, national, or international health. The regulations extend CDC authority wholly intrastatewhere people congregate to engage in travel or when the local or state authorities impose inadequate control measures. The CDC has the ability to stop citizens from traveling domestically or internationally. As such, it is very likely the CDC has the authority to stop a U.S. citizen, who is ill, from boarding an aircraft for an international flight.

COVID-19 presents specific new challenges to the rule of law and this discussion. The disease is thought to be spread from asymptomatic carriers. The CDC would not be able to rely on its authority over ill persons but would need to operate logistically over individuals in the precommunicable or qualifying stages of the illness. At these stages, the CDC's authority is mostly limited. Additionally, previous measures of reporting temperatures, as used during Ebola, would be ineffective on asymptomatic individuals. With this global pandemic unfolding, how the federal government will handle travel to and from the U.S. in unprecedented times is unknown. It will be interesting to see how far the CDC extends its quarantine authority during the current pandemic. 